\title{
EMPIRICAL STUDY ON RECREATION SUITABILITY EVALUATION OF SUBURBAN FOREST PARK - A CASE STUDY OF BAIYUN FOREST PARK IN LISHUI CITY, CHINA
}

\author{
ZHAO, M. ${ }^{1,2}-$ ZHANG, . ${ }^{*}-$ XIE, J. $^{3}-$ ZHANG, M. ${ }^{1}$ \\ ${ }^{I}$ School of Landscape and Architecture, School of Tourism and Health, Zhejiang Agriculture \& \\ Forestry University, 666 Wusu Street, Lin'an District, Hangzhou City, Zhejiang Province, China \\ (phone: +86-0571-6374-0102; fax: +86-0571-6374-3301) \\ ${ }^{2}$ Henan Urban Planning Limited Company, Zhengzhou City, 450000 Henan Province, China \\ ${ }^{3}$ Lishui Academy of Forestry, Lishui City, 323000 Zhejiang Province, China \\ *Corresponding author \\ e-mail: zhangjianguo2004@163.com; phone: +86-139-6803-0460; fax: +86-0571-6374-3301
}

(Received $12^{\text {th }}$ Oct 2018; accepted $16^{\text {th }}$ Jan 2019)

\begin{abstract}
Nowadays, suburban forest recreation is one of the most important forms of daily leisure activities of urban residents; therefore, it is of great significance to study the recreation suitability of suburban forest parks. On the basis of previous research results and in combination with the recreation suitability characteristics of the present suburban forest park, this paper uses the analytic hierarchy process (AHP) and the expert scoring method to build a suitability evaluation model. The results show that the model includes three criteria layers, 7 first-level index layers and 31 second-level index layers of resource conditions, basic conditions, and development and utilization conditions. In the distribution of index weight, that of resource conditions is the highest, followed by basic conditions and development and utilization conditions. Taking the Baiyun Forest Park in Lishui City, China, as an example, the scoring criteria of fuzzy comprehensive evaluation are adopted to evaluate its recreation suitability. The evaluation results show that the overall evaluation of recreation suitability of Baiyun Forest Park reaches the level of "good" and has a strong recreational nature. "Forest Resource", "Environment Quality" and "Location Condition" are rated excellent, while "human resources" and "supporting facilities" are rated average. Suggestions on developing forest natural resources, protecting the environment, earning positive cultural connotations, improving infrastructure and defining the tourist source market to enhance the suitability of recreation in parks are put forward on the basis of the evaluation result.
\end{abstract}

Keywords: forest park, recreation suitability, evaluation index system, analytic hierarchy process (AHP), fuzzy comprehensive evaluation method, Lishui City in China

\section{Introduction}

Recreation, a kind of entertainment method which allows people in modern society to relax themselves both physically and psychologically, refers to the leisure activities which individuals or groups take part in to feel pleased and satisfied in their spare time (Zhang, 2001) and the effect of the relaxation is amplified, when people can establish a positive connection to nature (Park et al., 2015). Forest recreation has become a tendency and fashion of modern ecological leisure activities. A forest park, due to its ecological system, mainly provides extraordinary environmental resources, health and fitness protection functions, sightseeing, recreation, sports and positive experiences to promote the soundness of body and mind for tourists. Recently, with the advance of industrialization and urbanization, many problems arise in human settlements. The suburban forest park is not only an important part of the urban ecological system, which provides ecological benefits and a pleasant landscape, but also promotes healthiness and 
fitness for people's body and mind while serving as a recreational site for the residents. Therefore, more and more cities have begun to construct suburban forest parks as "living" ecological systems (Wang et al., 2017) and the suburban forest park has become an important commodity for urban residents to form a healthy and civilized lifestyle.

With the recreation function of the suburban forest park gradually becoming the research focus, many scholars have done research and evaluation on the forest's recreation. America, as the most developed country in the aspect of forest recreation industry in the world at present, is the center of this research field, and the special research institutes are set up and the relevant managerial laws and regulations are formulated there (Qi et al., 1995). The foreign scholars think that the forest recreation is a summary of all the outdoor recreation forms which happen in the forest area, make statements about the planning, management, scientific research and selection of recreation location etc., learn about the tourists' needs about the urban forest recreation and the types of recreation activities and propose the suggestions on how to build a healthier and more comfortable environment (Douglas, 2000; Hunter, 2001). In recent years, some foreign scholars started from the forest's recreational value and did research on the leisure and entertainment value the forest can provide through the space analysis method (Baerenklau et al., 2010; Bestard and Font, 2010). Other foreign scholars analyzed the forest's spatial heterogeneity and the heterogeneity of tourists' preference through the research on the forest's property (Abildtrup et al., 2013; Termansen et al., 2013). The research into the forest recreation in China started a little late in early 1980s and afterwards, the construction and theoretical research into the forest recreation are gradually promoted (Liao, 2003). The State Forestry Administration of PRC has issued a series of laws and regulations successively to ensure the development of suburban forest parks (Chen and Wang, 1999). The scholars also do the research into the forest recreation from different aspects and angles. The research contents include: (1) The concept, characteristics and evaluation methods of forest recreation and so on (Chen and Shen, 2000); (2) The forest environment, animals and plants, and waters etc. such as monitoring the effect of the anion density and atmosphere quality inside the recreation area (He et al., 2015; Cai and $\mathrm{Gu}, 2005$ ); (3) The forest's recreation value etc. (Yang and Zhang, 2010). To analyze the level of all the aspects of suburban forest park comprehensively and accurately in the research, all the dynamic factors inside the park need monitoring and the comprehensive evaluation model such as the principal component analysis method (PCA), clustering analysis method, fuzzy comprehensive evaluation method and landscape visual evaluation method are used to make objective analysis (Wang et al., 2017; Qi et al., 2015).

There needs the further research on how to evaluate and analyze the recreation suitability of suburban forest park. The Baiyun Forest Park in Lishui City, China belongs to the typical suburban forest park with outstanding geographic position and good recreation conditions. The paper chooses the Baiyun Forest Park of Lishui as the empirical research subject for analysis and combines the expert scoring method, AHP and FCE together to evaluate and discuss the recreation suitability of suburban forest park. It aims to provide the beneficial reference for the development of leisure recreation function of the suburban forest park and offer some guidance for further improving and promoting the recreation activities of the suburban forest park. 


\section{Materials and methods}

\section{General description and data source of research area}

Baiyun Forest Park is $2 \mathrm{~km}$ away from the northern part of Lishui urban area in the mountain area of Southern Zhejiang and middle reaches of Oujiang River and is bounded by the urban area with superior location and convenient traffic. It mainly serves the residents living in and around the city with the total area of $26.71 \mathrm{~km}^{2}$. The geographic coordinates are east longitude $119^{\circ} 52^{\prime} \sim 119^{\circ} 58^{\prime}$ and northern latitude $28^{\circ} 23^{\prime} \sim 28^{\circ} 27^{\prime}$.

The hilly area in the park belongs to Xianxia Ridge remaining vein which rise amid permanent peaks with ups and downs. The highest altitude is $1073.2 \mathrm{~m}$. The geotectonic element of the park area belongs to Southern-east Zhejiang belt of folded strata which is mainly Longquan-Suichang broken rock with partial distribution of Cretaceous red sandstone and granite. There are a dozen of streams in the park which belong to Oujiang water system and among them, the largest one is Liyang pit and its total length is $9.5 \mathrm{~km}$. Besides, its length in the park is $5.3 \mathrm{~km}$ and the drop in elevation is $520 \mathrm{~m}$. The climate is mid semi-tropical monsoon climate with four distinctive dry and wet seasons as well as abundant rainfall. The average yearly temperature is $18.1^{\circ} \mathrm{C}$, the highest temperature of the year is $38^{\circ} \mathrm{C}$ (the extreme highest temperature in the urban area is $43.2^{\circ} \mathrm{C}$ ) and the lowest temperature of the year is $-7.7^{\circ} \mathrm{C}$ (the extreme lowest temperature of Taishan is $-14{ }^{\circ} \mathrm{C}$ ). The forest in the park is covered with lush vegetation and rich vegetation types and the coverage rate reaches $97.2 \%$. Besides the abundant natural resources, there are also profound human history and religious beliefs in the park.

The research data mainly come from the field investigation of Baiyun Forest Park with the method of recording, consulting the material on the Internet and questionnaire. First, do the field investigation in the park to have a rough understanding of the research area's topography, water system, landscape characteristics, vegetation planting and animals and plants resources etc. and then do the detailed survey and record the plant types, quantity, road condition and infrastructure condition etc. inside the research area in detail. Meanwhile, hand out the questionnaire to investigate the tourists' feelings about the park's recreation suitability. Lastly, sort out the field investigation condition and collected data and make analysis for the further research. The statistics in this paper come from the relative news website such as Lishui Statistics Information Network (http://tjj.lishui.gov.cn/sjjw/tjnj/201811/t20181119_3477511.htm;

http://www.lsnews.com.cn/images/gg_banmian/lyp_baiyunshang090915/gg_bys090915 .html).

\section{Research method}

\section{Expert scoring method}

Expert Scoring Method, also called "Delphi Method", refers to judging the current status and future trend of events by collecting experts' opinions and now it has been widely used in different subjects and organizations (Loo, 2002). The paper, on the basis of referring to a lot of research results about the related evaluation system and doing the field investigation, combines the own characteristics of suburban forest park and the conditions suitable for the recreation, summarizes the various analysis and research, concludes the primary index system of affecting the recreation suitability of suburban 
forest park and makes the questionnaire for 30 experts from related fields to judge and score. The related fields refer to the forest recuperation, forest health care-based tourism, ecotourism, town and country planning, and garden landscape. Experts are asked to assign the value to the importance "Score 1 for the Unimportant, Score 2 for the Less Important, Score 3 for the Important, Score 4 for the More Important, Score 5 for the Most Important" and screen the primary index. Through the multiple rounds of experts scoring and after consulting experts' comments, accepting the feedback and making adjustments multiple times, the index factors are screened, deleted and revised to perfect the whole index system and confirm the final evaluation index system (Table 1). The system is divided into the target layer, criterion layer, seven first-level index layers and 31 second-level index layers.

Table 1. Evaluation system for recreation suitability of suburban forest park

\begin{tabular}{|c|c|c|c|c|}
\hline Target layer & Criterion layer & First-level index & $\mathbf{S N}$ & Second-level index \\
\hline \multirow{7}{*}{$\begin{array}{l}\text { Recreation } \\
\text { suitability } \\
\text { evaluation of } \\
\text { Baiyun Forest } \\
\text { Park (A) }\end{array}$} & \multirow{3}{*}{$\begin{array}{c}\text { Resource } \\
\text { condition (B1) }\end{array}$} & $\begin{array}{l}\text { Forest resource } \\
\text { (C1) }\end{array}$ & $\begin{array}{l}\text { D1 } \\
\text { D2 } \\
\text { D3 } \\
\text { D4 }\end{array}$ & $\begin{array}{c}\text { Forest coverage rate } \\
\text { Forest impressions } \\
\text { Forest stand types } \\
\text { Forest canopy density }\end{array}$ \\
\hline & & $\begin{array}{l}\text { Landscape resource } \\
\text { (C2) }\end{array}$ & $\begin{array}{l}\text { D5 } \\
\text { D6 } \\
\text { D7 } \\
\text { D8 } \\
\text { D9 }\end{array}$ & $\begin{array}{c}\text { Landscape diversity } \\
\text { Landscape attraction degree } \\
\text { Landscape rarity } \\
\text { Landscape configuration } \\
\text { Wild animals }\end{array}$ \\
\hline & & $\begin{array}{l}\text { Human resources } \\
\text { (C3) }\end{array}$ & $\begin{array}{l}\text { D10 } \\
\text { D11 } \\
\text { D12 } \\
\text { D13 }\end{array}$ & $\begin{array}{c}\text { Human landscape } \\
\text { Cultural relics } \\
\text { Folk customs } \\
\text { Science education value }\end{array}$ \\
\hline & \multirow[t]{2}{*}{$\begin{array}{l}\text { Basic condition } \\
\text { (B2) }\end{array}$} & $\begin{array}{l}\text { Environment } \\
\text { quality (C4) }\end{array}$ & $\begin{array}{l}\text { D14 } \\
\text { D15 } \\
\text { D16 } \\
\text { D17 } \\
\text { D18 } \\
\text { D19 } \\
\text { D20 }\end{array}$ & $\begin{array}{c}\text { Air quality } \\
\text { Negative ion content } \\
\text { Surface water quality } \\
\text { Climate comfort level } \\
\text { Sanitary condition } \\
\text { Noise condition } \\
\text { Environment bearing capacity }\end{array}$ \\
\hline & & $\begin{array}{l}\text { Supporting facilities } \\
\text { (C5) }\end{array}$ & $\begin{array}{l}\mathrm{D} 21 \\
\mathrm{D} 22 \\
\mathrm{D} 23 \\
\mathrm{D} 24\end{array}$ & $\begin{array}{c}\text { Perfectness } \\
\text { Safety } \\
\text { Suitability } \\
\text { Humanization }\end{array}$ \\
\hline & \multirow{2}{*}{$\begin{array}{l}\text { Development } \\
\text { and utilization } \\
\text { condition (B3) }\end{array}$} & $\begin{array}{l}\text { Location condition } \\
\text { (C6) }\end{array}$ & $\begin{array}{l}\mathrm{D} 25 \\
\mathrm{D} 26 \\
\mathrm{D} 27 \\
\mathrm{D} 28\end{array}$ & $\begin{array}{c}\text { Geographic position } \\
\text { Regional economic level } \\
\text { Tourist source condition } \\
\text { Publicity degree } \\
\end{array}$ \\
\hline & & $\begin{array}{l}\text { Traffic condition } \\
\text { (C7) }\end{array}$ & $\begin{array}{l}\text { D29 } \\
\text { D30 } \\
\text { D31 }\end{array}$ & $\begin{array}{c}\text { External traffic system } \\
\text { Internal traffic system } \\
\text { Parking lot }\end{array}$ \\
\hline
\end{tabular}




\section{Analytic hierarchy process}

Analytic Hierarchy Process (AHP), which is proposed by T. L. Saaty, an American operational research expert in the early 1970s, is a systematic and hierarchy analysis method of confirming the weight factor by combining the qualitative and quantitative together (Chiclana et al., 1998). The method is applied to multiple research fields, such as commercial investment analysis (Aragonés-Beltrán et al., 2014), exploration planning (Rahmati et al., 2015) and multi-criteria decision analysis (Xu and Liao, 2014). The paper determines the evaluation index factor weight of suburban forest park recreation suitability with AHP.

\section{Build the structure model}

The research confirms the index factor after taking a lot of research data in the literature, the comments from the related experts and field investigation into consideration, unfolds the evaluation system of suburban forest park recreation suitability with Analytic Hierarchy Process (AHP) level by level and forms a multilayer and multidimensional index system with 4 layers and 31 evaluation index factors, as shown in Figure 1.

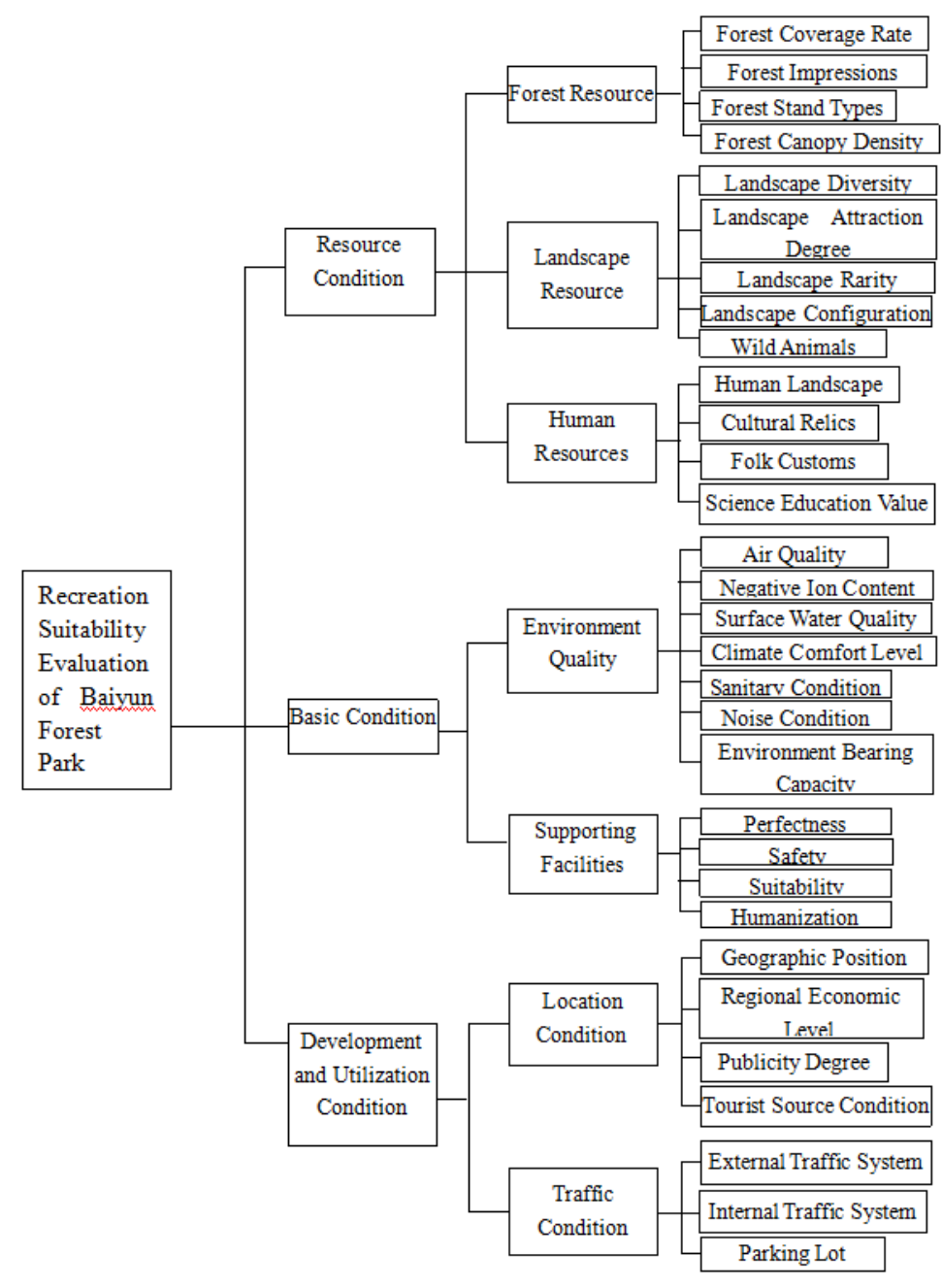

Figure 1. Hierarchical structure model of recreation suitability evaluation of suburban forest park 
Build the judgement matrix

The judgement matrix, which is built based on the above established evaluation model, is a prerequisite of doing the weight calculation and an important reference standard for sequencing. When building the judgement matrix, collect the related experts' comments about the index importance by the 1-9 proportional scaling method, get the average value of the obtained experts' valuation and build the judgement matrix initially and at the same time, make appropriate adjustments by referring to the research results of related fields at home and abroad. Lastly, the judgement matrix in the paper is built after combining the scores in the questionnaire and the related research.

Weight value calculation and conformity verification

After building the judgement matrix of each index, calculate the weight value. In this paper, the square root method is used to calculate the maximum characteristic root $\lambda_{\max }$, obtained by Equation 1, in which $\mathrm{W}$ is the characteristic vector corresponded with $\lambda_{\max }$. The characteristic vector is gained by the normalization processing of the vector. To get the rational and effective weight value, do the consistency verification test to the judgement matrix. Random consistency ratio $C R$ is obtained by Equation 2 and $C I$ can be obtained by Equation 3, in which $\mathrm{n}$ is judgement matrix order and RI is average random consistency ratio. When $C R=0$, the judgement matrix has the complete consistency; When $0<C R<0.1$, the judgement matrix conforms to the consistency requirement; When $C R \geq 0.1$, the consistency of the judgement matrix is not acceptable and all the factors of the matrix need adjusting again until it meets the requirement of consistency verification (Liu, 2012).

$$
\begin{gathered}
A W=\lambda_{\text {max }} W \\
C R=\frac{C I}{R I} \\
C I=\frac{\lambda_{\text {max }}-n}{n-1}
\end{gathered}
$$

Do the normalization processing to the weight of all the index factors according to the above method, get the weight value of each index through calculation and make the importance sequencing, namely, overall ranking (Table 2).

\section{Fuzzy comprehensive evaluation method}

The fuzzy comprehensive evaluation method is used to do the quantitative comprehensive evaluation to the recreation suitability of Baiyun Forest Park and the final score obtained in this way will determine the recreation suitability of Baiyun Forest Park. It is highly scientific and reliable to use the fuzzy comprehensive evaluation method, which combines the fuzzy theory and math model (Jiao et al., 2016) and does a quantitative analysis to the fuzzy object so as to get a comparatively scientific result (Ye, 2010). First, build a fuzzy comprehensive evaluation set of evaluation factors and then the judgement set $\mathrm{V}=(\mathrm{V} 1, \mathrm{~V} 2, \mathrm{~V} 3 \ldots \mathrm{Vm})$. Usually, the fuzzy five-point scale scoring system is used and it is classified into five levels: V1 
stands for "Excellent", V2 for "Good", V3 for "Average", V4 for "Bad" and V5 for "Very Bad" (Wang et al., 2017; Xue, 2011). The fuzzy scoring standard of each index factor in the evaluation system is made in accordance with the above requirement, as shown in Table 3.

Table 2. Evaluation index weight of recreation suitability of suburban forest park

\begin{tabular}{|c|c|c|c|c|c|c|c|}
\hline Target layer & $\begin{array}{c}\text { Criterion } \\
\text { layer }\end{array}$ & Weight & Factor layer & Weight & Index layer & Weight & Sequencing \\
\hline \multirow{7}{*}{$\begin{array}{l}\text { Recreation } \\
\text { suitability } \\
\text { evaluation of } \\
\text { suburban } \\
\text { forest park A }\end{array}$} & \multirow{3}{*}{$\begin{array}{c}\text { Resource } \\
\text { condition B1 }\end{array}$} & \multirow{3}{*}{0.625} & $\begin{array}{l}\text { Forest resource } \\
\text { C1 }\end{array}$ & 0.405 & $\begin{array}{l}\text { Forest coverage rate D1 } \\
\text { Forest impressions D2 } \\
\text { Forest stand types D3 } \\
\text { Forest canopy density D4 }\end{array}$ & $\begin{array}{l}0.211 \\
0.082 \\
0.081 \\
0.031\end{array}$ & $\begin{array}{c}1 \\
2 \\
3 \\
11\end{array}$ \\
\hline & & & $\begin{array}{l}\text { Landscape resource } \\
\text { C2 }\end{array}$ & 0.144 & $\begin{array}{c}\text { Landscape diversity D5 } \\
\text { Landscape attraction degree D6 } \\
\text { Landscape rarity D7 } \\
\text { Landscape configuration D8 } \\
\text { Wild animals D9 }\end{array}$ & $\begin{array}{l}0.026 \\
0.047 \\
0.033 \\
0.025 \\
0.013 \\
\end{array}$ & $\begin{array}{c}14 \\
6 \\
9 \\
15 \\
21\end{array}$ \\
\hline & & & $\begin{array}{l}\text { Human resources } \\
\text { C3 }\end{array}$ & 0.076 & $\begin{array}{c}\text { Human landscape D10 } \\
\text { Cultural relics D11 } \\
\text { Folk customs D12 } \\
\text { Science education value D13 }\end{array}$ & $\begin{array}{l}0.020 \\
0.039 \\
0.009 \\
0.006 \\
\end{array}$ & $\begin{array}{c}18 \\
7 \\
25 \\
28\end{array}$ \\
\hline & \multirow[t]{2}{*}{$\begin{array}{c}\text { Basic } \\
\text { condition B2 }\end{array}$} & \multirow[t]{2}{*}{0.238} & $\begin{array}{l}\text { Environment quality } \\
\text { C4 }\end{array}$ & 0.179 & $\begin{array}{c}\text { Air quality D14 } \\
\text { Negative ion content D15 } \\
\text { Surface water quality D16 } \\
\text { Climate comfort level D17 } \\
\text { Sanitary condition D18 } \\
\text { Noise condition D19 } \\
\text { Environment bearing capacity D20 }\end{array}$ & $\begin{array}{l}0.056 \\
0.034 \\
0.014 \\
0.028 \\
0.012 \\
0.032 \\
0.008 \\
\end{array}$ & $\begin{array}{c}5 \\
8 \\
20 \\
12 \\
22 \\
10 \\
26 \\
\end{array}$ \\
\hline & & & $\begin{array}{l}\text { Supporting facilities } \\
\text { C5 }\end{array}$ & 0.060 & $\begin{array}{c}\text { Perfectness D21 } \\
\text { Safety D22 } \\
\text { Suitability D23 } \\
\text { Humanization D24 } \\
\end{array}$ & $\begin{array}{l}0.023 \\
0.024 \\
0.005 \\
0.007\end{array}$ & $\begin{array}{l}17 \\
16 \\
29 \\
27\end{array}$ \\
\hline & \multirow{2}{*}{$\begin{array}{c}\text { Development } \\
\text { and } \\
\text { utilization } \\
\text { condition B3 }\end{array}$} & \multirow[t]{2}{*}{0.137} & $\begin{array}{l}\text { Location condition } \\
\text { C6 }\end{array}$ & 0.034 & $\begin{array}{c}\text { Geographic position D25 } \\
\text { Regional economic level D26 } \\
\text { Tourist source condition D27 } \\
\text { Publicity degree D28 }\end{array}$ & $\begin{array}{l}0.017 \\
0.004 \\
0.010 \\
0.003\end{array}$ & $\begin{array}{l}19 \\
30 \\
24 \\
31\end{array}$ \\
\hline & & & $\begin{array}{l}\text { Traffic condition } \\
\text { C7 }\end{array}$ & 0.103 & $\begin{array}{c}\text { External traffic system D29 } \\
\text { Internal traffic system D30 } \\
\text { Parking lot D31 }\end{array}$ & $\begin{array}{l}0.066 \\
0.027 \\
0.011\end{array}$ & $\begin{array}{c}4 \\
13 \\
23\end{array}$ \\
\hline
\end{tabular}

After building the factor set, quantify every factor of the evaluation subject. According to the evaluation standard, design the questionnaire to investigate the tourists and the related working staffs of Baiyun Forest Park and carry out a statistical analysis on the investigation results to get the fuzzy relationship judgement matrix:

$$
R=\left\{\begin{array}{cccc}
r_{11} & r_{12} & \ldots & r_{1 m} \\
r_{21} & r_{22} & \ldots & r_{2 m} \\
\ldots & \ldots & \ldots & \ldots \\
r_{n 1} & r_{n 2} & \ldots & r_{n m}
\end{array}\right\} .
$$


Then get the factor weight $\mathrm{W}=\left(\mathrm{W}_{1}, \mathrm{~W}_{2}, \mathrm{~W}_{3} \ldots \mathrm{W}_{\mathrm{m}}\right)$ according to the weight value of each index confirmed by the AHP, work out the comprehensive judgement result in accordance with Equation 4 and then gain the final evaluation level according to the maximum membership principle.

$$
V i=W i * R i
$$

Table 3. Fuzzy scoring criteria for evaluation factors of recreation suitability of Baiyun Forest Park

\begin{tabular}{|c|c|c|c|c|c|c|}
\hline \multirow{2}{*}{ Target layer } & \multirow{2}{*}{ Data source } & \multicolumn{5}{|c|}{ Index score } \\
\hline & & 5 & 4 & 3 & 2 & 1 \\
\hline Forest coverage rate & Statistical data & $\geq 90 \%$ & $80 \% \leq X<90 \%$ & $70 \% \leq X<80 \%$ & $60 \% \leq X<70 \%$ & $<60 \%$ \\
\hline Forest impressions & Questionnaire & More beautiful & Beautiful & Average & $\mathrm{Bad}$ & Very bad \\
\hline Forest stand types & Statistical data & More & Many & Average & Few & Less \\
\hline $\begin{array}{c}\text { Forest canopy } \\
\text { density }\end{array}$ & Questionnaire & Higher & High & Average & Low & Lower \\
\hline Landscape diversity & Questionnaire & Higher & High & Average & Low & Lower \\
\hline $\begin{array}{c}\text { Landscape attraction } \\
\text { degree }\end{array}$ & Questionnaire & Higher & High & Average & Low & Lower \\
\hline Landscape rarity & Questionnaire & Higher & High & Average & Low & Lower \\
\hline $\begin{array}{l}\text { Landscape } \\
\text { configuration }\end{array}$ & Questionnaire & More beautiful & Beautiful & Average & Bad & Very bad \\
\hline Wild animals & Statistical data & $\geq 50$ Types 种 & $40 \leq X<50$ & $30 \leq X<40$ & $20 \leq X<30$ & $<20$ \\
\hline Human landscape & Questionnaire & More beautiful & Beautiful & Average & Bad & Very bad \\
\hline Cultural relics & Statistical data & $\begin{array}{l}\text { National level } \\
\text { with huge } \\
\text { influence }\end{array}$ & $\begin{array}{c}\text { Provincial level } \\
\text { with comparatively } \\
\text { big influence }\end{array}$ & $\begin{array}{l}\text { Municipal level } \\
\text { with average } \\
\text { influence }\end{array}$ & $\begin{array}{c}\text { Not in the } \\
\text { protection list with } \\
\text { small influence }\end{array}$ & $\begin{array}{l}\text { With no } \\
\text { influence }\end{array}$ \\
\hline Folk customs & Questionnaire & Much dense & $\begin{array}{c}\text { Comparatively } \\
\text { dense }\end{array}$ & Average & Thin & Thinner \\
\hline $\begin{array}{c}\text { Science education } \\
\text { value }\end{array}$ & Questionnaire & Higher & High & Average & Low & Lower \\
\hline Air quality & \begin{tabular}{|l|} 
Questionnaire \\
\end{tabular} & Excellent & Good & Average & Poor & Poorer \\
\hline Negative ion content & Statistical data & $\geq 12000$ & $8000 \leq X<12000$ & $5000 \leq X<8000$ & $2000 \leq X<5000$ & $<2000$ \\
\hline Surface water quality & Statistical data & I Type & II Type & III Type & IV Type & V Type \\
\hline $\begin{array}{c}\text { Climate comfort } \\
\text { level }\end{array}$ & Statistical data & $\geq 300$ Days & $250 \leq X<300$ & $150 \leq X<250$ & $100 \leq X<150$ & $<100$ \\
\hline Sanitary condition & Questionnaire & Excellent & Good & Average & $\mathrm{Bad}$ & Very bad \\
\hline Noise condition & Statistical data & $\leq 40 \mathrm{~dB}$ & $40 \leq X<50$ & $50 \leq X<60$ & $60 \leq X<70$ & $\geq 70$ \\
\hline $\begin{array}{l}\text { Environment bearing } \\
\text { capacity }\end{array}$ & Statistical data & $\geq 5000$ People & $4000 \leq X<5000$ & $3000 \leq X<4000$ & $2000 \leq X<3000$ & $<2000$ \\
\hline Facility perfectness & \begin{tabular}{|l|} 
Questionnaire \\
\end{tabular} & Excellent & Good & Average & $\mathrm{Bad}$ & Very bad \\
\hline Facility safety & Questionnaire & Excellent & Good & Average & $\mathrm{Bad}$ & Very bad \\
\hline Facility suitability & Questionnaire & Excellent & Good & Average & $\mathrm{Bad}$ & Very bad \\
\hline $\begin{array}{c}\text { Facility } \\
\text { humanization }\end{array}$ & Questionnaire & Excellent & Good & Average & Bad & Very bad \\
\hline Geographic position & statistical data & \begin{tabular}{|c|} 
The distance \\
between it and \\
the central city is \\
$\leq 10 \mathrm{~km}$ \\
\end{tabular} & $10<\mathrm{X} \leq 30$ & $30<\mathrm{X} \leq 50$ & $50<\mathrm{X} \leq 70$ & $>70$ \\
\hline Service facility & Questionnaire & Excellent & Good & Average & $\mathrm{Bad}$ & Very bad \\
\hline Publicity degree & Questionnaire & Bigger & Big & Average & Small & Smaller \\
\hline $\begin{array}{l}\text { Tourist source } \\
\text { condition }\end{array}$ & Statistical data & Richer & Rich & Average & Not rich & Poor \\
\hline $\begin{array}{l}\text { External traffic } \\
\text { system }\end{array}$ & Statistical data & \begin{tabular}{|} 
There is direct \\
public \\
transportation \\
and it is much \\
convenient to get \\
there
\end{tabular} & $\begin{array}{c}\text { Comparatively } \\
\text { convenient }\end{array}$ & Average & $\begin{array}{l}\text { There is difficulty } \\
\text { in arriving there } \\
\text { directly and it is } \\
\text { inconvenient }\end{array}$ & $\begin{array}{l}\text { Terrible } \\
\text { traffic } \\
\text { conditions }\end{array}$ \\
\hline $\begin{array}{c}\text { Internal traffic } \\
\text { system }\end{array}$ & Questionnaire & Excellent & Good & Average & $\mathrm{Bad}$ & Very bad \\
\hline Parking lot & Questionnaire & More & Many & Average & Few & Less \\
\hline
\end{tabular}


To show the recreation suitability of Baiyun Forest Park more clearly and directly, it is necessary to figure out the final scores of each index factor and the whole respectively of recreation suitability. First, assign the value $V_{1}=5, V_{2}=4, V_{3}=3, V_{4}=2, V_{5}=1$ to each judgement set in the $V=\left\{V_{1}, V_{2}, V_{3}, V_{4}, V_{5}\right\}$ respectively and get the scores of each factor according to Equation 5.

$$
W_{A}=\sum_{k=1}^{n} B_{A k} V_{k}
$$

in which, $\mathrm{B}_{\mathrm{Ak}}(\mathrm{k}=1,2,3,4,5)$ is the $\mathrm{kth}$ membership of $\mathrm{B}_{\mathrm{A}}$.

\section{Results and analysis}

\section{Analysis on the suburban forest park index factor weight}

Through the above calculation and statistical analysis, it can be concluded that in the evaluation system of suburban forest park recreation suitability, the total weight value of criterion layer B is 1 . The result shows that the sequence of the three index factors in the criterion layer is resource condition $(0.625)>$ basic condition $(0.238)>$ development and utilization condition (0.137) and the resource condition accounts for most, which indicates that in the suburban forest park recreation, the resource condition is the most important and it is also an essential factor of attracting the tourists. Whether the forest park has the suitable condition for the tourists to have recreation largely depends on whether it has the excellent resource condition or not. The basic condition and the development and utilization condition rank second and third and the weight difference between the two is not big, which means that in the recreation suitability, there is a lot of upside potential for the basic condition and the development and utilization condition, which also are the indispensable condition in the suburban forest park recreation suitability evaluation system.

In the criterion layer, the importance order of index factor in the resource condition (B1) is forest resource $(0.405)>$ landscape resource $(0.144)>$ human resources $(0.076)$, and the forest resource accounts for a large part, which indicates that in the suburban forest park resource condition, the forest resource is the most important, next is the landscape resource, which is followed by human resources. This shows that in the forest park, the natural and ecological forest resource can attract a lot of tourists to come here for recreation and the human resources have the smallest influence in the forest park. In the forest resource, the weight value $(0.211)$ of forest coverage rate is the largest index weight and also the factor whose weight ranks first in the whole evaluation index system. This reflects that the higher forest coverage rate in the suburban forest park is of great significance to attract the tourists.

In the basic condition (B2), the importance order of index factor is environment quality $(0.170)>$ supporting facilities (0.060). For the suburban forest park, the outstanding environment quality still appeals to many tourists, which directly affects the recreation suitability. Since the environment quality has a big influence on the people's body and mind and nowadays people have a preference for the health care-based tourism, the weight ratio of forest park environment quality is comparatively big and that of the supporting facilities is relatively small. In the development and utilization condition (B3), the importance order of index factor is traffic condition (0.103) > 
location condition (0.034). The suburban forest park needs to have the superior geographic position. The traffic condition has the direct limitation and influence on the number of tourists, so the traffic condition is of great importance to the park recreation. Besides, the location condition is also important, because if the suburban forest park is in the remote and inaccessible area, there will be fewer tourists, it will be not suitable for recreation and it is also hard to give a full play to its original value.

\section{Analysis on the recreation suitability of Baiyun Forest Park}

The calculation result obtained according to the fuzzy comprehensive evaluation method is the final score of Baiyun Forest Park recreation suitability. The evaluation level can be gained according to the corresponding evaluation index factor. From the above evaluation result, get all the levels of Lishui Baiyun Forest Park recreation suitability and the specific evaluation level of each evaluation factor, as shown in Table 4 .

Table 4. Summary of fuzzy comprehensive evaluation results of Baiyun Forest Park

\begin{tabular}{|c|c|c|c|c|c|c|c|}
\hline Target layer & $\begin{array}{c}\text { Evaluation } \\
\text { score }\end{array}$ & $\begin{array}{l}\text { Criterion } \\
\text { layer }\end{array}$ & $\begin{array}{c}\text { Evaluation } \\
\text { score }\end{array}$ & $\begin{array}{l}\text { First level } \\
\text { index }\end{array}$ & $\begin{array}{c}\text { Evaluation } \\
\text { score }\end{array}$ & Second level index & $\begin{array}{c}\text { Evaluation } \\
\text { score }\end{array}$ \\
\hline \multirow{7}{*}{$\begin{array}{l}\text { Recreation } \\
\text { suitability } \\
\text { evaluation of } \\
\text { Baiyun } \\
\text { Forest Park A }\end{array}$} & \multirow{7}{*}{3.809} & \multirow{3}{*}{$\begin{array}{c}\text { Resource } \\
\text { condition B1 }\end{array}$} & \multirow{3}{*}{3.842} & $\begin{array}{c}\text { Forest } \\
\text { resource C1 }\end{array}$ & 4.104 & $\begin{array}{c}\text { Forest coverage rate D1 } \\
\text { Forest impressions D2 } \\
\text { Forest stand types D3 } \\
\text { Forest canopy density D4 }\end{array}$ & $\begin{array}{l}4.32 \\
4.27 \\
3.74 \\
3.28\end{array}$ \\
\hline & & & & $\begin{array}{c}\text { Landscape } \\
\text { resource C2 }\end{array}$ & 3.509 & $\begin{array}{c}\text { Landscape diversity D5 } \\
\text { Landscape attraction degree D6 } \\
\text { Landscape rarity D7 } \\
\text { Landscape configuration D8 } \\
\text { Wild animals D9 }\end{array}$ & $\begin{array}{l}4.46 \\
4.04 \\
3.03 \\
3.45 \\
1.90 \\
\end{array}$ \\
\hline & & & & $\begin{array}{c}\text { Human } \\
\text { resources C3 }\end{array}$ & 3.166 & $\begin{array}{c}\text { Human landscape D10 } \\
\text { Cultural relics D11 } \\
\text { Folk customs D12 } \\
\text { Science education value D13 }\end{array}$ & $\begin{array}{l}3.41 \\
3.11 \\
2.35 \\
3.52 \\
\end{array}$ \\
\hline & & $\begin{array}{c}\text { Basic } \\
\text { condition B2 }\end{array}$ & 3.967 & $\begin{array}{c}\text { Environment } \\
\text { quality C4 }\end{array}$ & 3.992 & \begin{tabular}{|c|} 
Air quality D14 \\
Negative ion content D15 \\
Surface water quality D16 \\
Climate comfort level D17 \\
Sanitary condition D18 \\
Noise condition D19 \\
Environment bearing capacity D20
\end{tabular} & $\begin{array}{l}4.58 \\
4.61 \\
3.08 \\
4.05 \\
4.39 \\
4.39 \\
4.12 \\
\end{array}$ \\
\hline & & & & $\begin{array}{c}\text { Supporting } \\
\text { facilities C5 }\end{array}$ & 3.091 & $\begin{array}{c}\text { Perfectness D21 } \\
\text { Safety D22 } \\
\text { Suitability D23 } \\
\text { Humanization D24 }\end{array}$ & $\begin{array}{l}3.04 \\
2.86 \\
3.65 \\
3.57\end{array}$ \\
\hline & & $\begin{array}{c}\text { Development } \\
\text { and } \\
\text { utilization }\end{array}$ & 3.735 & $\begin{array}{c}\text { Location } \\
\text { condition C6 }\end{array}$ & 3.745 & $\begin{array}{c}\text { Geographic position D25 } \\
\text { Regional economic level D26 } \\
\text { Tourist source condition D27 } \\
\text { Publicity degree D28 }\end{array}$ & $\begin{array}{l}4.08 \\
3.91 \\
3.56 \\
2.34 \\
\end{array}$ \\
\hline & & condition B3 & & $\begin{array}{c}\text { Traffic } \\
\text { condition C7 }\end{array}$ & 3.736 & $\begin{array}{c}\text { External traffic system D29 } \\
\text { Internal traffic system D30 } \\
\text { Parking lot D31 }\end{array}$ & $\begin{array}{l}3.98 \\
3.45 \\
2.97\end{array}$ \\
\hline
\end{tabular}


It is concluded from the evaluation result that the final score of Baiyun Forest Park recreation suitability is 3.809 and the whole evaluation result is "Good". Based on the divided evaluation set score, the recreation suitability of Baiyun Forest Park belongs to the good level with strong recreation suitability. The evaluation result complies with the actual fact of the park. In the criterion layer, the basic condition is rated as "Excellent" and the resource condition and development and utilization condition are rated as "Good"; In the first level index, the forest resource, environment quality and location condition are rated as "Excellent", the landscape resource and traffic condition are rated as "Good" and the human resources and supporting facilities are rated as "Average"; In the second level index, such factors as forest coverage rate, landscape diversity, air quality, negative ion content, sanitary condition, noise condition, geographic position and external traffic system are rated as "Excellent", the factors such as forest impressions, forest stand types, landscape attraction degree, landscape configuration, climate comfort level, environment bearing capacity, regional economic level and tourist source condition are rated as "Good" and the factors such as forest canopy density, landscape rarity, human landscape, cultural relics, science education value, surface water quality, facility suitability, facility humanization, internal traffic system and parking lot are rated as "Average"; the factors such as folk customs, facility safety and publicity degree are rated as "Bad" and the only factor that is rated as "Very Bad" is wild animals. Based on the result, in the suburban forest park, the most important things are still the rich forest resource, outstanding environment quality and superior location condition. The fact that Baiyun Forest Park is in the suburb makes the unique location condition, which increases the park's recreation suitability.

\section{Resource condition evaluation}

Based on the evaluation result, the general evaluation result of Baiyun Forest Park in the aspect of resource condition is "Good". In it, the "Forest Resource" is rated as "Excellent", which indicates that Baiyun Forest Park has rich forest resource with good quality, high forest coverage rate, good forest impressions, causing the strong overall recreation suitability. "Landscape Resource" is rated as "Good", which shows the whole landscape is beautiful. However, "Landscape Rarity" is rated as "Average", which means that many tourists think the landscape in the park is too common with no distinctive characteristics; "Wild Animals" is rated as "Very Bad", indicating that there are nearly no wild animals. "Human Resources" is rated as "Average", which is unsatisfactory. For example, the insufficient cultural deposits, the unattractive human landscape, few cultural relics, thin folk custom atmosphere and low science education value, lowering the recreation suitability relatively. Some profound historical cultural value is not utilized effectively, showing that the park needs to strengthen the preservation and exploitation in these aspects, especially the development of culture history and science education.

\section{Basic condition evaluation}

Based on the evaluation result, the general evaluation result of Baiyun Forest Park in the aspect of basic condition is "Excellent". In it, the comprehensive evaluation result of "Environment Quality" is "Excellent" and the level of air quality and negative ion content is the highest in the evaluation layer of each item; the sanitary condition and noise condition are rated as "Excellent"; the climate comfort level and environment 
bearing capacity are rated as "Good", showing the environment quality of Baiyun Forest Park is good, which is beneficial for the health care and leisure recreation as well as the well-being of people's body and mind. The surface water quality is rated as "Average" and it is found that the water body surface in the park is partially polluted; therefore, the improvement of surface water quality in the park should be one of the most important problems to be solved. The support facilities are rated as "Average". The public toilet, road signs, shopping and accommodation and catering service are imperfect and not all of tourists' needs can be met. Whether the supporting facilities are perfect or not will affect the park's recreation suitability to a large extent, therefore, the perfectness, safety and humanization of supporting facilities in the park need further improving.

\section{Development and utilization condition evaluation}

Based on the evaluation result, the general evaluation result of Baiyun Forest Park in the aspect of development and utilization condition is "Good". "Location Condition" is rated as "Excellent". In it, the geographic position is rated "Excellent", indicating that Baiyun Forest Park is a typical suburban forest park with clear location advantage. The superior geographic position strengthens the park's recreation suitability. The tourist source condition and geographic position have mutual effect on each other. Because the park's geographic position is superior, the tourist source condition is rated as "Good"; the publicity degree is rated as "Bad". Although all the conditions of Baiyun Forest Park are good, the publicity is far from enough, therefore, it ss necessary to strengthen the publicity degree; "Traffic Condition" is rated as "Good" and the external traffic system is rated as "Excellent", which means that people have easy access to Baiyun Forest Park. It is found in the investigation that there are many buses in the downtown by which people can get to the park gate directly and this also strengthens the park's recreation suitability. The internal traffic system and the parking lot are rated as "Average", indicating they cannot meet tourists' requirements and need further improving.

\section{Discussion and conclusion}

1. The paper, by using the expert scoring method, systematically builds the suburban forest park recreation suitability evaluation system which includes 4 layers with 31 index factors after multiple rounds of screening and adjusting. The system is made up of three criteria layers, including the resource condition, basic condition, development and utilization condition, in which the resource condition and basic condition are the prerequisite and material guarantee and development and utilization condition is the factor affecting the coordination of forest park recreation suitability.

2. Confirm the weight value of all the index factors with the AHP and, on this basis, adopt the fuzzy comprehensive evaluation method to do the empirical study to Baiyun Forest Park in the Lishui city. Based on the evaluation result, the score of Baiyun Forest Park is 3.809 out of 5, indicating that the recreation suitability belongs to the good level. With the superior natural resource condition, environment quality and geographic position, the park has obvious tourism location advantage and high recreation suitability. Based on the fuzzy comprehensive evaluation result, the factors rated as "Excellent" include the "Forest Resource", "Environment Quality" and "Location Condition", showing that Baiyun Forest Park has rich forest resource, excellent environment, fresh air, which are important characteristic resources of Baiyun Forest 
Park and are beneficial for the recreation suitability. Besides, Baiyun Forest Park has the superior geographic position and increasing the accessibility to the park will increase the tourist amount. "Human Resources" and "Supporting Facilities" are rated as "Average", indicating that problems exist in these two aspects of Baiyun Forest Park and they need further improving.

3. Due to the limitation of its own resource condition, there is difficulty in improving the recreation suitability greatly for Baiyun Forest Park. In the recreation development, put much emphasis on the forest health care function, make full use of the advantage of rich forest resource, strengthen the appreciation of multi-seasonal colored plants, keep the environment not being polluted continuously, clarify the park's tourist source market, mainly base the development on the Lishui city as well as the surrounding counties and cities, dig the inherent cultural resource, rebuild the characteristic landscape, strengthen the publicity degree and meanwhile, improve the bearing capacity of recreation infrastructure to increase the park's recreation suitability.

\section{REFERENCES}

[1] Abildtrup, J. et al. (2013): Spatial preference heterogeneity in forest recreation. Ecological Economics 92: 67-77.

[2] Aragonés-Beltrán, P. et al. (2014): An AHP (Analytic Hierarchy Process)/ANP (Analytic Network Process)-based multi-criteria decision approach for the selection of solarthermal power plant investment projects. - Energy 66: 222-238.

[3] Baerenklau, K. A. et al. (2010): Spatial allocation of forest recreation value. - Journal of Forest Economics 16(2): 113-126.

[4] Bestard, A. B., Font, A. R. (2010): Estimating the aggregate value of forest recreation in a regional context. - Journal of Forest Economics 16(3): 205-216.

[5] Cai, B., Gu, X. (2005): The impacts of forest recreation on ecological environment and the countermeasures against its negative impacts. - Journal of West China Forestry Science 34(1): 74-77.

[6] Chen, X., Shen, G. (2000): Dissection of some concepts about forest recreation. - World Forestry Research 13(1): 69-76.

[7] Chen, X., Wang, Y. (1999): Review of development of forest recreation. - World Forestry Research 6: 32-37.

[8] Chiclana, F. et al. (1998): Integrating three represen-taion models in fuzzy multipurpose decision making based on fuzzy preference relations. - Fuzzy Sets and Systems 7: 3348.

[9] Douglas, R. W. (2000): Forest Recreation (5th Ed.). - Waveland Press, Illinois.

[10] He, P. et al. (2015): Spatiotemporal distribution and influence factors of negative air ion in forest recreation areas across Xinjiang. - Resources Science 37(3): 629-635.

[11] Hunter, I. R. (2001): What do people want from urban forestry? - The Europe experience. - Urban Ecosystem 5: 277-284.

[12] Jiao, J. et al. (2016): Assessment of surface ship environment adaptability in seaways: A fuzzy comprehensive evaluation method. - International Journal of Naval Architecture \& Ocean Engineering 8(4): 344-359.

[13] Liao, R. (2003): The history and the prospect of forest recreation. - Journal of Sichuan Agricultural University 21(2): 168-171.

[14] Liu, M. (2012): Research on Evaluation and Construction of Landscape Resource in Mount Tai. - Shandong Agricultural University, Shandong. 
[15] Loo, R. (2002): The Delphi method: a powerful tool for strategic management. Policing: An International Journal of Police Strategies \& Management 25(4): 762-769.

[16] Lu, Q. et al. (1995): Review and prospect of the national parks in the world. - World Forestry Research 1: 34-40.

[17] Park, B. J. et al. (2015): Physiological effects of forest recreation in a young conifer forest in Hinokage Town, Japan. - Silva Fennica 43(2): 291-301.

[18] Qi, J. et al. (2015): Landscape visual evaluation of Qishan National Forest Park based on GIS and SBE method. - Journal of Northwest Forestry University 30(2): 245-250.

[19] Rahmati, O. et al. (2015): Groundwater potential mapping at Kurdistan region of Iran using analytic hierarchy process and GIS. - Arabian Journal of Geosciences 8(9): 70597071 .

[20] Termansen, M. et al. (2013): Modelling and mapping spatial heterogeneity in forest recreation services. - Ecological Economics 92: 48-57.

[21] Wang, N. et al. (2017): SBE-based evaluation of in-forest landscape aesthetic quality of forest park in suburb. - Journal of Northwest Forestry University 32(1): 308-314.

[22] Wang, Y. et al. (2017): Comprehensive evaluation about healthcare function of typical forest communities in Qishan Mountain in Fuzhou. - Journal of Northwest Forestry University 32(4): 63-68.

[23] Xu, Z., Liao, H. (2014): Intuitionistic fuzzy analytic hierarchy process. - IEEE Transactions on Fuzzy Systems 22(4): 749-761.

[24] Xue, X. (2011): Comprehensive evaluation of Qiqushan National Forest Park recreation suitability. - Journal of Yangtze University 8(11): 229-233.

[25] Yang, Z., Zhang, Y. (2010): Value evaluation of Jinggangshan Forest recreation resources based on contingent value method. - Journal of Beijing Forestry University 9(4): 53-58.

[26] Ye, Z. (2010): Study and Application of Fuzzy Comprehensive Evaluation Based on AHP. - South China University of Technology, Guangzhou.

[27] Zhang, X. (2011): Study on the planning and design of recreational project - discuss and analyze on its setting and method. - Chinese Gardening 2: 11-13. 